\title{
Assessing the Impact of Macroeconomic Variables on the Performance of the U.S. Stock Market
}

\author{
Eric Inkoom Danso \\ School of Science, Zhejiang University of Science and Technology, No. 318, \\ Hangzhou, Zhejiang, 310023, China
}

\begin{abstract}
Using S\&P 500 and Dow Jones Industrial Average indices as the benchmark to measure the U.S. stock market, the study focused on assessing the effects macroeconomic variables on the performance of stock market. Using multiple regression model, the study found a negative correlation of unemployment rate and GDP growth rate on the stock market performance but established a direct relation with inflation and the stock market performance. The study concluded that, the negative relationship with GDP growth rate was because the U.S. stock market tracks its performance from the global technology industry rather than economic growth whiles unemployment rate was due to the fact that, depending on the economic scenario, this variable affects the stock market differently. However, the direct relationship between the inflation because a high inflation rate reduces the purchasing power which affects the number of stocks bought and the income generated from the stock market.
\end{abstract}

Keywords: Stock Market, Economic Growth, Macroeconomic Indicator, United States, Developed Country

DOI: $10.7176 /$ RJFA/11-14-08

Publication date:July $31^{\text {st }} 2020$

\section{Introduction}

For years since the emergence of finance and stock market, many researchers and theorists have been fascinated by the relationship existing amongst the returns of stock market and macroeconomic indicators. Contributing to the existing literature, (Gurley \& Shaw 1955; 1960; 1967) argued that, "financial development is basic positive function of real income". This emphasized the relationship existing between the financial market and economic growth rate. Duca (2007) also argued that there exist a strong correlation between economic activities and the returns from the stock market, on condition that the stock price represents the discounted present value of the company $\left[^{1}\right]$. However, there have been conflicting and inconclusive results from empirical evidence on the the economic variables are factored into the stock prices (Lai, 2005) $\left[{ }^{2}\right]$.

With financial market, different countries practices different model depending on the type of government and the regime in power (Najeb, 2013). In Europe, Germany and other Eastern European countries practices the bankbase model $\left[{ }^{3}\right]$ whereas the U.K and the U.S. practices the market-based $\left[{ }^{4}\right]$ model of financial market (Najeb, 2013). Tracing back to $19^{\text {th }}$ century, many economists have been assessing both models in an attempt to indentify the model type that promotes long-run economic growth. In the context of bank-based model, economists argues that they are better for mobilizing savings, application of sound corporate control and best model to adopt particulrly at the begninning cycle of economic development and in a weak instutional environment. Whereas, the market-based model emphasizes on allocating capital with accompanying risk management tools, and eliminating the problems associated with excessively powerful banks (Ross, 2002). Despite the lasting arguments and insights by different economic theorists, the International Monetary Fund and the World Bank directed countries practising bank-based system to adopt capitalism primarily due to the failures from socialism that was being practised by most of these economies. In view of this, the World Bank $(1989,1994)$ argued for the estblishment and promotion of stock market in order to rescue their economy.

The objective of the study was to assess the impact macroeconomic variables have on the returns from the stock market in United States using the S\&P 500 and Dow Jones Industrial Average Indices as the benchmark.

\subsection{Literature Review}

2.1 Stock Market

The stock market is an avenue where securities are traded. Stapley (1986) argues that, the stock market is key to

1 They emphasized that the interaction of the returns of stock and macroeconomic indicators premises on the notion that returns from the stock market are impacted by macroeconomic variables such as inflation, interest rates, exchange rate and Gross Domestic Product (GDP), because the payout from the stock market forms a function of the economic activity (Bodie, Kane \& Marcus, 2008; Duca, 2007; Patro, Wald \& Wu, 2002)

2 The actual interactive activities of stock prices and economic indicators continues to remain a mystery in the financial industry

3 In the bank-based model, the bank plays a primary role in mobilizing funds and savings, capital allocation, supervision of investment decisions made by the corporate management and providing risk management vehicles to ensure safe and sound investment (Aslh, 1999).

4 In the market-based model, the securities markets share center stage with banks in terms of getting society's savings to firms, exerting corporate control, and easing risk management (Aslh, 1999) 
structural transformation in economies from the traditional, insecure bank-based and rigid to a more flexible and invulnerable to surprises, variabilities and lack of investors' confidence. The stock market is a market where shares, bonds, cattle or fruits traded between individuals or organizations over the internet or a phone call. Patrick and Wai (1973) defines stock market as those markets that allows companies to generate capital (short - and longterm) and investors to own equities. This activity of buying and selling stocks and shares is highly significant in capital allocation within economies (Pratten, 1993). Also, Pratten (1993) argues that selling and buying stocks and shares provides the investors with a signal of market value of their investment which may ultimately influence their consumption decision. The development and facilitation of the stock market promotes efficient resource mobilization and allocation to the various sectors of the economy which promote economic growth (Errunza, 2001). According to Chatziantniou et al. (2013), the stock market can spearhead the direction and performance of all sectors of the economy and as such, provides an alternative route for transmission mechanism for policy action.

In light of establishing the roles and functions of the stock market, Fabozzi et al. (2002) established three roles for the market: (1) the interactions of buyers and sellers determines the price of the traded asset; the market provides an avenue for buyers and sellers to sell and buy their assets; and the market reduces cost of transactions.

\subsubsection{Importance of Stock Market to Economic Growth}

According to Islam \& Watanapalachaikul (2005), stock market performance determines the wealth and performance of an economy. The market can be regard as a cornerstone that spearhead the smooth transfer of funds primarily for economic growth (Zafar, 2008) [1]. Levine (1996) agreed with Islam \& Watanapalachaikul and emphasized that, the stock market perform an important financial function in any given economy by ensuring an efficiency in capital allocation to promotes economic growth through the mobilization of savings, provision of liquidity, risk diversification and provide some form of corporate control. The market also allows private firms to raise long-term capital through the issuance of equity to finance their businesses (Feldman \& Kumar, 1995; Rousseau \& Wachtel, 2000). Levine $(1991,1996)$ furthered the linkage by arguing that the stock market can influence economic growth through their liquidity to ensure firm investments are not interrupted.

\subsubsection{The United States Stock Performance Indexes}

\subsubsection{The Dow Jones Industrial Average Index (DJI)}

The oldest index in the stock market, the DJI was developed by Charles Dow and it consists of 30 of the largest and most influential companies often referred as the blue-chip companies. This index reflects the current business climate in the U.S. because it is about a quarter of the value of the entire stock market and a change in the index represents a change in investors' earning and risk expectations of the large corporations included in the index (Statefarm, n.d.; Caroline, 2020) $\left[{ }^{2}\right]$. The DJI uses the share prices in with a divisor in its weightings instead of using market capitalization to arrive at a final value.

\subsubsection{The Standards and Poor (S\&P) 500 Index}

This is a market-cap weighted index that shows the change in total stock performance and the value of the companies included in the index. The S\&P 500 comprises of 500 of the largest companies in the U.S. To be included in the index, a particular keen interest in liquidity, public float, sector classification, financial viability and liability is taken into account. The index represents about $80 \%$ approximation of total value of the U.S stock market (StateFarm, n.d.; Caroline, 2020). The S\&P 500 is calculated by weighting the market capitalization of the companies included in the indexand dividing it with a divisor set by the S\&P.

\subsubsection{The Nasdaq 100}

This is a market capitalization technology focused index that features over 100 largest traded and international non-financial business in the U.S. This index is the only U.S based having international companies included: Willis Towers Watson (Ireland); ASML Holdings (Netherlands), ets.

\subsubsection{The Current Research in focus}

There is a strong correlation between all these indices as they trade the performance of companies under the same business environment affected by the same macroeconomic variables. However, the DOW is often criticized for its failure to keep abreast with the current or new economy and also its continuous effort to maintain the oldfashioned ways of weightings. Despite these criticisms, the DOW has performed better in the last 5years (an annualized 12.4\%) than the S\&P 500 (annualized 11.4\%) (Barry, 2019). It is necessary to point that, the DOW has the least volatility among all the major indices and lacks marquee technology stocks like AMAZON, GOOGLE, and uses share price in its weightings instead of market capitalization. These reasons present the DOW as the best index for this current research to ascertain the overview of economic performance of the last decade.

\subsection{Macroeconomic Variables}

In the context of this paper, the literature on the U.S macroeconomic indicators was screened to include the

\footnotetext{
${ }^{1}$ The stock market facilitates liquidity of the financial market, diversify risks and allocate resources to the most important investment opportunities. The stock market is considered the "lifeblood of an economy" (Levine, 1997; Zafar, Urooj and Durrani, 2008).

${ }^{2}$ The enlisted companies in DOW, because they reflect the general outlook, received a bailout from the U.S. Government to offsets some loss and pay loans in wake of the Covid-19 to spearhead the economic recovery process.
} 
variables that affect the financial markets especially the equity markets since the theme for the paper concerns on the risks imposed by macroeconomic variables on stock performance, the variables that will be included are: inflation rate, unemployment rates, and the Gross Domestic Product.

\subsubsection{Gross Domestic Product}

Over the years, there have been debates within empirical researchers, investors and other players in the financial industry on the correlation that exists between economic growth and returns from the stock market. In recent times, emerging economies have been experiencing consistent economic growth and players in the finance industry contemplate whether they should allocate a higher weight to the economy based on the GDP rather than market capitalization (MSCI, 2010). In an attempt establish the link, several researchers found the link between stock market returns and GDP to be negative (Dimson et at., 2002; Ritter, 2005; MSCI, 2010). MSCI, using data from 1958 - 2008 on developed economies had a result of negative correlation between economic growth and returns from stock market. In theoretical setting, faster growth in economy suggests faster growth in sales for companies which potentially increases the returns from the stock market, but in reality, there are other underlying factors that affect returns from the stock market rather than the economic growth outlook $\left.{ }^{1}\right]$ (Kleintop, 2018).

\subsubsection{Consumer Price Index (Inflation)}

The measurement of weighted average price of basket of consumer goods and service, the consumer price index is considered a very vital macroeconomic variable often used to ascertain the relationship macroeconomic variables have with the performance of the stock markets (Hussainey and Ngoc, 2009; Schlögl, 2018). Many researchers (Nasseh and Strauss, 2000; Wongbangpo and Sharma, 2002; Gunasekarage et al., 2004) argued that the $\mathrm{CPI}\left[{ }^{2}\right]$ is one specific factor often used as proxy to represent many macroeconomic indicators such as discount rate, inflation and the goods market: Gunasekarage et al. (2004) found the CPI as proxy to inflation had significant impacts on the Sri Lanka Stock market; using the CPI as proxy to goods market, Wongbangpo and Sharma (2002) studied the effects goods market on five Asian (Singapore, Malaysia, Philippines, Indonesia and Thailand) countries and found a negative impact between the CPI and the stock prices. This research supported the longstanding research works by Fama \& Schwert (1997), Sweeney \& Warga (1986) and Jain (1988) who had longed believed that CPI has negative correlation with stock markets. Recent study by Adams, McQueen \& Wood (2004) built on that assertion and found that 1\% change in Consumer Price Index reduced the stock market returns by $-1.289 \%$ on intraday basis. This work furthered the argument that CPI (inflation) negatively impact the returns from the stock market not only in the long-term but also in the short-term. Notwithstanding, a research by Nasseh and Strauss (2000) found a positive correlation between high inflation high stock prices. In the nutshell, there is a directly correlation between CPI and the performance or returns from the stock market

\subsubsection{Unemployment Rate}

Although, there seem to be conflicting findings from various literature on the actual effect of unemployment rate on stock returns, this indicator over the years proves to be critical since it directly affects the spending capacities of the individual. Nikkinen, et al. (2006) revealed that reports from employment statistics is critical to the wide measure of the economy, which directly affects the financial market. McQueen \& Roley (1993) argued that an unexpected decrease in the rate of unemployment led to the reduction of stock price by $2.2 \%$. Nonetheless, recent studies provide contradictions to the existing consensus. According to Boyd \& Jagannathan (2005), depending on the state of the economy, unemployment rates affect the returns from the stock market. To them, during economic recession, a positive news from employment data will affects stock prices positively whereas during economic expansion, a positive data from employment data will cause stock prices to fall. Further, Birz \& Lott (2011) did not find any actual effect of unemployment on stock prices, particularly with S\&P 500 data from $1991-2004$.

\subsection{Methodological Approach for the Research \\ 3.1 Data}

The data on Inflation Rate, Gross Domestic Product Growth Rate [ ${ }^{3}$, Unemployment Rate and Stock Prices was taken January 2010 - March 2020. The Stock Price data $\left[{ }^{4}\right]$ was obtained from Yahoo Finance $\left[{ }^{5}\right]$ and data on all the macroeconomic indicators were obtained from the U.S. Bureau of Economic Analysis $\left.{ }^{6}\right]$

\footnotetext{
${ }^{1}$ Jeffery Kleintop of Charles Schwab compared the relationship between economic growth and stock market returns in the three largest developed economies of the world (U.S., Germany and Japan). In his analysis, there was an absolute disconnection between GDP and stock market in all three economies.

Rather, he emphasized that Japan's stock market tracks the performance of global financial stocks, Germany's stock market tracks the performance of global automakers whiles the U.S. stock market tracks the performance of global technology sector (Kleintop, 2018).

${ }^{2}$ The paper used inflation figures as a proxy of CPI in its analysis.

${ }^{3}$ Due to quarterly data on GDP Growth Rate, all other data was converted into Quarterly data by the researcher.

${ }^{4}$ The DJI and S\&P 500 were used as the benchmark in measuring the overall performance of the U.S. Stock Market

A 10-year Historical data on the Dow Jones Industrial Average Index (DJI) and S\&P 500 were obtained from https://finance.yahoo.com/quote/\%5EDJ/history?p=0 05 EDJ https://finance.yahoo.com/quote $/ \% 5$ EGSPC/history? $\mathrm{p}=\% 5 \mathrm{EGSPC}$

${ }^{6}$ Bureau of Economic Analysis, U.S [https://www.bea.gov/]
} 


\subsection{Model Construction and Estimation Approach}

The study will first obtain the general impact of macroeconomic variables on stock market performance with the model 1 using the DJI as the benchmark

$\mathrm{SP}_{\mathrm{DJI}}=\beta_{0}+\beta_{1 \text { GDPGR }}+\beta_{2} \mathrm{INF}_{\mathrm{t}}+\beta_{3 \mathrm{UNM}}$

The study will further test the same economic variables on S\&P 500 index in attempt to measuring the performance using the S\&P 500 as the benchmark

SPS\&P00 $=\boldsymbol{\beta}_{0}+\beta_{1 G D P G R}+\beta_{2 \mathrm{INF}_{\mathrm{t}}}+\boldsymbol{\beta}_{3} \mathbf{U N M} \mathbf{M}_{\mathrm{t}}$

The SP $=$ Stock Price (DJI and S\&P 500) at the specified date range, GDPGR $\mathrm{t}_{\mathrm{t}}=$ the Gross Domestic Product Growth Rate of the U.S. at the stipulated time range, $\mathrm{INF}_{\mathrm{t}}=$ the U.S. inflation rate within the specified date range, and $\mathrm{UNM}_{\mathrm{t}}=$ the Unemployment Rate within the study date range.

\subsection{Results and Discussion}

Table 2: Regression Model of Macroeconomic Impact of the performance of DJI \& S\&P500

\begin{tabular}{|c|c|c|c|c|c|c|c|c|}
\hline & \multicolumn{2}{|c|}{ Estimate } & \multicolumn{2}{|c|}{ Std..Error } & \multicolumn{2}{|c|}{ t.value } & \multicolumn{2}{|c|}{$p$-value } \\
\hline & S\&P 500 & DJI & S\&P 500 & DJI & S\&P 500 & DJI & S\&P 500 & DJI \\
\hline (Intercept) & 3752.494 & 32598.046 & 90.15063 & 1022.925 & 41.6247059 & 31.8674783 & $1.11 \mathrm{E}-32$ & $1.67 \mathrm{E}-28$ \\
\hline GDPGR & -1811.589 & -7977.956 & 1996.03025 & 22648.644 & -0.9075962 & -0.3522487 & $3.70 \mathrm{E}-01$ & $7.27 \mathrm{E}-01$ \\
\hline INF & 9778.032 & 115637.417 & 11035.82517 & 125221.789 & 0.8860263 & 0.9234608 & $3.81 \mathrm{E}-01$ & $3.62 \mathrm{E}-01$ \\
\hline UNM & -28195.078 & -239520.67 & 1236.52424 & 1022.925 & -22.8018809 & -17.071248 & $2.21 \mathrm{E}-23$ & $3.95 \mathrm{E}-19$ \\
\hline
\end{tabular}

Significant at $5 \%$

The above table give the model construction below:

Model 1 [ $\mathrm{SP}_{\mathrm{DJI}}=32598.046-7977.956 \mathrm{GDPGR}+115637.417 \mathrm{INF}-239520.67 \mathrm{UNM}$ ]

Model 1 [SP SP $500=3752.494-1811.589 G D P G R+9778.032 \mathrm{INF}-28195.078 \mathrm{UNM}$

From the above table shows the Multiple Regression Model to presents the impact macroeconomic indicators on the performance of U.S. Stock market. The output shows that Inflation (INF) had a significant relationship with the stock market whiles the Unemployment and GDP Growth Rate showed negative correlation with both indices of the U.S. stock market. From the table, $1 \%$ change in Inflation causes about $88.60 \%$ change in the S\&P 500 and $92.34 \%$ change in the Dow.
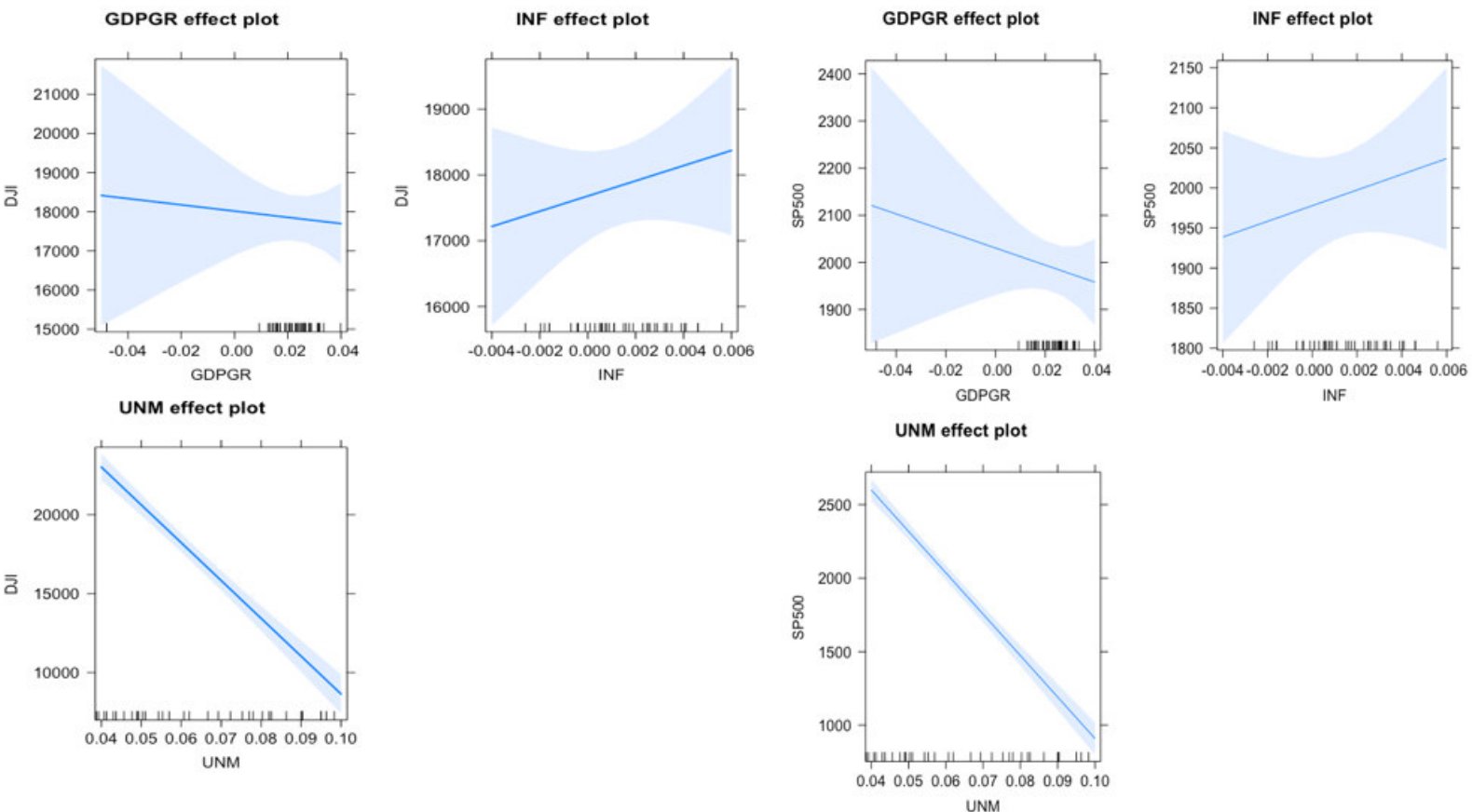

Figure 1: The Effects of Macroeconomic Variables on the performance of DJI and S\&P 500

The figure above elaborate the actual effects of the macroeconomic variables on the performance of both DJI and S\&P 500. There was a direct positive correlation between the Inflation variable and the performance of both Indices. These results collaborate with the findings of Fama \& Schwert (1997), Sweeney \& Warga (1986), Jain (1988) Gunasekarage et al (2004) who longed argued that Inflation (CPI) has a direct relationship with the performance of the stock market. From the above graph, it indicated that the prevailing inflation rate in the U.S. directly influenced the performance of the stock market. Thus; a direct change in inflation had a direct impact on 
the performance of both the DJI and S\&P. Unemployment regressed negatively with the performance of the two indices which further highlights the research findings of Boyd \& Jagannathan (2005), who argued that depending on the economic state of the country, unemployment rates affects the stock market differently. However, from the findings of this research, unemployment rate does not affect the U.S stock market performance using the DJI and S\&P 500 as the benchmark. GDP Growth rate also had an inverse relationship with the performance of the stock market and this result agrees with the findings of Dimson et at., 2002; Ritter, 2005; MSCI, 2010. Kleintop (2008) who suggested that intuitively, economic performance should directly reflect with the performance of stock market but in reality, the returns from the stock market premises on other factors - in U.S, the market tracks the performance of the global technology sector.

\subsection{Conclusion}

This research focused on establishing the effects macroeconomic indicators have on the performance of U.S. stock market using both S\&P and Dow Jones Industrial Average as the benchmark. The research employed regression analysis and showed that inflation (INF) had a direct correlation on the performance of both stock indices. This relationship could be explained by the fact that an unexpected increase in inflation causes a decrease in the purchasing power - thus; few stocks will be bought which directly affects the income from stock prices to the corporations.

The negative impact GDP Growth rate showed could be explained by establishing that in theory, an economic growth should translate to positive performing stock market but in real economy, there are other underlying factors that drive economic growth which does not directly affect the stock market whereas there are other underlying factors that drives the performance of stock market which does not directly causes economic growth. In the case of U.S. stock market, it had been established that it tracks its performance from the global technology industry rather than economic growth and that explains the negative relationship the regression model showed.

Unemployment also regressed negatively because depending on the economic scenario at that particular time, it affects the stock market differently. During contractionary economic scenario, high unemployment rates largely affect the performance of the stock market and in expansionary economic scenario, high unemployment rate has less significant effect on the performance of the stock market

\section{References}

Adams, G. McQueen, G., \&. Wood, R. (2004). The Effects of Inflation News on High Frequency Stock Returns. The Journal of Business , pp. 77(3), 547-574..

Aslh, D.-K. Ross, L., (1999). Bank-Based and Market-Financial systems tend to bemore market-based In higherBased Financial System: Cross-country Comparisons, s.1.: The World Bank.

Barry, A., (2019). The S\&P 500 Is Stocks' Modern Benchmark. But the Old-Fashioned Dow Has Beat It Over the Past 5 Years.. [Online] Available at: https://www.barrons.com/articles/dow-jones-industrial-average-s-p500-weightings-composition-51576705240

Birz, G. \&. Lott, J. R. (2011). The effect of macroeconomic news on stock returns: New evidence from newspaper coverage. ournal of Banking \& Finance, pp. 35(11), 2791-2800.

Bodie, Z. K. A. \&. Marcus, J., (2008). Investments, 7th edition. New York: McGraw- Hill/Irwin..

Boyd, J. H. Hu, J. \&. Jagannathan, R. (2005). The Stock Market's Reaction to Unemployment News: Why Bad News Is Usually Good for Stocks. The Journal of Finance, pp. 60(2), 649-672.

Caroline, B. (2020). An Introduction to U.S. Stock Market Indexes. [Online] Available at: https://www.investopedia.com/insights/introduction-to-stock-market-indices/\#the-dow-jones-industrialaverage

Chatziantoniou, I. David. D., \& George, F. (2013). Stock market response to monetary and fiscal policy shocks: Multi-country evidence. Economic Modelling, pp. 30(C), 754-769 .

Dimson, E., Paul, M. \&. Mike. S. (2002). Triumph of the Optimists: 101 Years of Global Investment Returns. Princeton: Princeton University Press.

Duca, G. (2007). The relationship between the stock market and the economy: experience from international financial markets. Bank of Valletta Review, p. 36.

Errunza, V. (2001). Foreign Portfolio Equity Investments, Financial Liberalization, and Economic Development. Review of International Economics , pp. 9(4):703-26.

Fabozzi. J., Modigaliani, F. Jones, F., \& Ferri. M. (2002). Foundations of Financial Markets and Institutions. (3rd ed.). s.l.:earson Education LTD..

Fama, E. F. \&. Schwert, W. G. (1977). Asset Returns and Inflation. Journal of Financial Economics, pp. 6(2), $115-146$.

Feldman, R. A. \&. Kumar. M. S. (1995). Emerging equity markets: Growth, benefits and policy concerns.. The World Bank Research Observer, pp. 10 (2), 181-200

Gunasekarage, A., Pisedtasalasai. A. \& Power, D. ( 2004). Macroeconomic influence on the stock market evidence 
from an emerging market in South Asia. Journal of Emerging Market Finance, pp. Vol. 3, 285-304.

Gurley, J. G. \& Shaw, E., (1955). Financial Aspects of Economic Development. American Economic Review, pp. 45(4), 515-538..

Gurley, J. \& Shaw, E. (1960). Money in a Theory of Finance. Washington D.C.: he Brookings Institution.

Gurley, J. \& Shaw, E. (1967). Financial Development and Economic Development. Economic Development and Cultural Change, pp. 15(3), 257-268.

Hussainey, K. \&. Lee, N. K. (2009). The Impact of Macroeconomic Indicators on Vietnamese Stock Prices. The Journal of Risk Finance, pp. Vol. 10, Iss.4, 321-332..

Islam, S. \&. Watanapalachaikul, S. (2005). Empirical finance: modelling and analysis of emerging financial and stock markets.. New York: Physica-Verlag..

Jain, P. C. (1988). Response of Hourly Stock Prices and Trading Volume to Economic News. The Journal of Business, pp. 61(2), 219-231.

Kleintop, J. (2018). What Does GDP Mean For The Stock Market?. [Online] Available at: https://www.schwab.com/resource-center/insights/content/what-does-gdp-mean-stock-market

Lai, C. \&. Roy, A. (2005). The effects of macroeconomic news announcements on mean stock return.. s.1.:Proceedings of the Midwest Business Economics Association..

Levine, R. \&. Zervos S. (1996). Stock market development and long-run growth. The World Bank Economic Review, pp. 10(2), 323-339.

Levine, R. (1991). Stock Market, Growth, and Tax Policy. Journal of Finance, pp. 46(4), 1445-65.

Levine, R. (1996). Stock Markets: A Spur to Economic Growth. Article Based on 12 Papers Presented at a World Bank conference. Washington D.C, World Bank.

McQueen, G. \&. Roley, V. V. (1993). Stock prices, news, and business conditions. Review of Financial Studies, pp. 6(3), 683-707. .

MSCI, (2010). Is There a Link Between GDP Growth and Equity Returns?. [Online] Available at: https://www.msci.com/documents/10199/a134c5d5-dca0-420d-875d-06adb948f578

Najeb, M. M. (2013). The Impact of Stock Market Performance upon Economic Growth. International Journal of Economics and Financial Issues, pp. Vol. 3 (4) 788-798.

Nikkinen, J., Omran,. M, Sahlström. P. \&. Ä. J. (2006). Global stock market reactions to scheduled U.S. macroeconomic news announcements. Global Finance Journal, pp. 17(1), 92-104..

Patrick, H. Wai, U. (1973). Stock and Bond Issues and Capital Markets in Less Developed Countries. Washington, D.C.: nternational Monetary Fund, Staff Papers, World Bank.

Patro, D., Wald. J. \&. Wu, Y. (2002). The impact of macroeconomic and financial variables on market risk: Evidence from international equity returns. European Financial Management, pp. 8, pp. 421-447..

Pratten, C. (1993). The Stock Market. London: Department of Applied Economics, University of Cambridge..

Ritter, J. R. (2005). Economic growth and equity returns. Pasific-Basin Finance Journal, pp. 13, 489 - 503.

Ross, L. (2002). BANK-BASED OR MARKET-BASED FINANCIAL SYSTEMS:WHICH IS BETTER?, Cambridge: NATIONAL BUREAU OF ECONOMIC RESEARCH.

Rousseau, P. L. \&. Wachtel, P. (2000). Equity markets and growth: Cross-country evidence on timing and outcomes. ournal of Business and Finance, pp. 24, 1933-1957. .

Schlögl, H. T. (2018). Macroeconomic Indicators and Systematic Risk - Is there a difference between Emerging and Developed Markets?. [Online] Available at: https://bibliotecadigital.fgv.br/dspace/handle/10438/20145

Stapley, N. (1986). he Stock Market: A Guide for the Private Investors. London: Faulkner in Association with Laing and Cruickshank Investment Management Services..

StateFarm, (n.d). Using indexes to measure stock market performance. [Online] Available at: https://www.statefarm.com/simple-insights/planning/using-indexes-to-measure-stock-market-performance

Sweeney, R. J. \&. Warga, A. D. (1986). The Pricing of Interest-Rate Risk: Evidence from the Stock Market.. The Journal of Finance, pp. 41(2), 393-410..

Wongbangpo, P. \&. Sharma, S. C. (2002). Stock market and macroeconomic fundamental dynamic interactions: ASEAN-5 countries. ournal of Asian Economics, pp. Vol. 13, Issue 1, 27-51..

Zafar, N. Urooj, S. \&. Durrani, T. (2008). Interest Rate Volatility and Stock Return and Volatility. European Journal of Economics, Finance and Administrative Sciences, pp. 14, 2887.

\section{Author Biography}

Eric Inkoom Danso, born on December 22, 1992 is currently studying MS Applied Statistics at Zhejiang University of Science and Technology and newly admitted MS Applied Financial Economics student at Saint Louis University, Missouri, United States (Fall 2020). He is an Associate Member of the Royal Institute of Chartered Surveyors, United Kingdom since 2019. He holds a bachelor degree in Real Estate from the University for Development Studies, WA, Ghana in 2017. 